\title{
CARMEN MIRANDA'S WHITE DRESS: ETHNICITY, SYNCRETISM AND SUBALTERN SEXUALITIES IN SPRINGTIME IN THE ROCKIES
}

José Gatti

Universidade Federal de São Carlos

\section{Abstract}

This essay calls for a reassessment of Carmen Miranda's work in Hollywood. Her singing and dancing can reveal unexpected ethnic and cultural alignments. The focus here is on the costumes she designed for Springtime in the Rockies, a Fox musical in which Brazilian as well as Native American cultural references are made explicit in Miranda's performance.

Keywords: Politics of representation; nationality; ethnicity; cinema.

In 1942, three years after she had disembarked in the U.S., Carmen Miranda had already won international recognition and was receiving one of the highest salaries in Hollywood. A meteoric career for an artist who presented a totally outlandish image to the North-American public. In that year she would take part in her fourth feature film, Springtime in the Rockies (Irving Cummings, 1942), a film intended to be a vehicle for the Good Neighbor Policy of the Roosevelt administration. As happened to other

\begin{tabular}{|l|l|l|l|l|}
\hline Ilha do Desterro & Florianópolis & no 51 & p. 093- 108 & jul./dez. 2006 \\
\hline
\end{tabular}


films that featured Miranda, Springtime in the Rockies had an ambiguous reception in Brazil: audiences and critics oscillated between repulsion and fascination. Brazilians recognized the conquests of the rising star but found it hard to identify with that highly stylized image. Nevertheless, it seems indisputable that that image became omnipresent in the world, with recognition coming from all latitudes. Miranda was impersonated, imitated and admired by many; her persona inspired filmmakers in such faraway places as Egypt and the Phillipines; her outfits became a staple for transvestites and drag queens in several countries; her figure became a logo for a fruit company. It wouldn't be too daring to say that Carmen Miranda became one of the key-images of the $20^{\text {th }}$ century. In this sense, she can be seen as a doorway for the understanding the evolution of the culture industry, the women's role, ethnic differences as well as the international geopolitics of her time. Miranda went far beyond the role of Brazilian cultural ambassador in the United States and Springtime in the Rockies - as well as her other Hollywood films, strangely ignored by Brazilian cultural critics - can provide us with elements in order to reevaluate the universal appeal of her translation of Brazil.

From that film, I want to focus particularly on her rendition of the musical number Tique-taque do meu coração (by Valfrido Silva and Alcyr Pires Vermelho), in which she shows unexpected ethnic and political articulations.

Miranda's career, until the eve of her death, was marked by her professionalism and, at the same time, by a quest for constant innovation. Her persona on radio, stage and screen had already been established in Brazil when she left for the U.S.. Her repertoire could be traditional, romantic or even provocative and parodic, full of tonguetwisting lyrics. She recorded songs by some of the most important Brazilian authors of her time, such as Joubert de Carvalho, Ary Barroso, Vicente Paiva, Assis Valente and many others. In the words of composer and singer Caetano Veloso, before her departure she had

abundantly registered her particular reinvention of samba (...) Her fascinating songbook received a precious treatment 
according to her dynamic and spontaneous style. The agility of her diction and her sense of humor, thrown into the rhythm, could only have sprung from a very clever mind. ${ }^{1}$

Although she kept in touch with tradition, having adopted the pronunciation of the previous generation of singers (she kept the vibrant " $\mathrm{r}$ ", for instance, that was used by singers such as Francisco Alves and Vicente Celestino), Carmen was always aware of new languages as well as new technological developments of the radio, the recording industry and the cinema. That's why she would be nicknamed, by the trade papers, "lady of the secrets of the microphone". In fact, she was one of the first Brazilian artists to master the intricacies of the electrical recording, that came to Brazil in the late 1920's. In the history of Brazilian popular music Miranda can be seen as a pioneer, next to her good friend Mário Reis, who used the microphone in a way that would be standard only two decades later, by bebop and bossa nova singers.

Morever, when she left Brazil, Miranda had already taken part in several Brazilian films, having been directed by the prominent Humberto Mauro and Adhemar Gonzaga, among others.

In this essay I intend to focus on Miranda's work from an auteur perspective-which might sound useless since she was often defined as "creative". I believe the biographical accounts often forget she was the author of her persona. Most of what has been written in Brazil depicts her as a victim, as a martyr that met her fateful death in 1955, when she was only 44 years old. These narratives usually downplay the importance of her work in Hollywood and tell us of the failures in her attempts to take "Brazilian culture" to the United States-and the stylization of her wardrobe was among the favorite targets of her Brazilian critics, who found it excessive. These criticisms were usually informed by notions of authenticity and nationalism, ${ }^{2}$ and ignored the possibilities of adaptation, transformation and - especially — the politics of the symbolic as proposed by Miranda. What I propose here is that from a perspective of the politics of representation-understood here as a space of continuous negotiation-Miranda's oeuvre will have to be reexamined. 
In this sense, in order to see her as a multiauthor-chanteuse, choreographer, costume designer-one needs to be able to evaluate the space of negotiation she effectively conquered in Hollywoodand not necessarily what she could not achieve. It is well known that producers meddled with her work; they determined, for instance, that she would be relegated to supporting roles (despite the fact that she had the highest salary) and that she kept her heavy accent (despite the fact that she spoke fluent English in a matter of months). On the other hand, it seems that she kept more decision power regarding her repertoire, choreography and costumes. Her talent would become raw material for screenwriters, producers, choreographers and directors. They would write countless lines with jokes and puns referring to Miranda's outfits; they would decide gestures inspired in her choreographies; they would compose tableaux, choose colors and produce backprojections according to the light reflected in her face.

Since the beginnings of her career her performance included original choreographies, such as the one that can be seen with her sister Aurora in the Brazilian film Alô, alô, Carnaval (Adhemar Gonzaga, 1936) and especially that which would establish a standard: her interpretation of Que é que a baiana tem? in Banana da terra (João de Barro, 1939). In this film, she dons the baiana outfit for the first time and sings with a group led by Dorival Caymmi, who composed the song. As João Luiz Vieira puts it, in this number

the bracelets, the turban, the earrings, the baubles and trinkets, the very high footstools and the silk midriff, along with the gestures rehearsed by Caymmi, epitomize in her artistic persona the juxtapostion of Brazilian popular music and other symbols of our tropical culture. ${ }^{3}$

Many decades later, Dorival Caymmi told researcher Ana Rita Mendonça that during the production of Banana da terra he would take Carmen Miranda to the dressmaker (who happened to be the wife of celebrated composer Vicente Paiva, of Mamãe eu quero). "Caymmi 
recalls the Argentinian fabric Carmen chose, with red, green and yellow stripes. Later, he'd help her choose the trinkets, in the shops of [downtown Rio]. And on the shooting day he helped her develop the gestures with her hands. ${ }^{\prime 4}$ Carmen added fruits to the turban, in order to evoke the African-Brazilian street vendors, as well as the priestesses of the candomblé (or santería) religion, many of them immigrated from the state of Bahia to Rio. That costume had already been popular in Carnival festivities since the beginning of the $20^{\text {th }}$ century, as can be seen in photographs and films of the period. Miranda would redesign the baiana several times, fitting it to plot needs. She was fully equipped to produce her own costumes, since she had learned designing and sewing with her older sister Olívia and worked as a hatmaker in trendy shops of downtown Rio. ${ }^{5}$ João Luiz Vieira asserts that

It was probably due to her work in the world of fashion that Carmen developed a sharp intuition about the role of costumes in a dialogue with the body, an organically experienced relationship that she fully controlled. ${ }^{6}$

Thus the turban could turn into a basket of fruits, flowers, jinglebells or even a cargoload of several tons coming down from a crane of an oceanliner, such as in the opening scene of The gang's all here (Busby Berkeley, 1943). The skirt could be in different colors, patterns and lengths; the famous baubles and trinkets could be in metal, stones or mere cloth pendants, seeming to have been stolen from some curtains. And her high clogs, which helped her look taller on the stage, resulted in fashion trends as well as in absurd rumors (that she did cocaine in the heels of her pumps, for instance).

However, biographer Cássio Emmanuel Barsante warns that

It's important to note that Carmen Miranda's success was not exclusively due to her baiana outfits. She was not the first to wear it, neither in Brazil nor in Hollywood. In 1928, singer Aracy Cortes was a hit in vaudeville acts wearing the typical 
outfit of the women from [Bahia] and there was a period in which costumes of sailors and baianas were simply forbidden [in the elegant balls of Rio], for they were considered too vulgar.

That's why, according to Caymmi, Miranda hesitated before she wore it before the camera in Banana da terra. However, after the film became a hit, the costume was once again worn by high society women in the salons of Rio. ${ }^{8}$ She would also use the baiana outfits as part of a public relations strategy: she gave it to several celebrities who happened to visit Rio. When Tyrone Power came in 1938, newspapers registered that his fiancée Annabella received a baiana from Miranda. The same would happen to actress-skater Sonja Heine.

And many years after her death, years during which her presence in the Brazilian imaginary was an obstacle to "our ideals of good taste and national identity", in the words of Caetano Veloso, ${ }^{9}$ Miranda and her baiana would be recuperated by the avant-garde Tropicalist Movement of the late 1960's, in a parodic yet deeply affectionate manner. Miranda's work reemerged once again as necessary. Veloso writes that Tropicalism

took her as one of its main signs, turning the malaise evoked by her name and her gestures into a revitalized provocation of the minds that lived through a time of drunkeness in political and aesthetic utopias, in a country that sought its place within modernity and suffered a military dictatorship. ${ }^{10}$

Thus, I believe that in order to understand this unfinished trajectory, so often confused with the search for our own imagined identity, it will be worthwhile to revisit some moments of Carmen Miranda's career, both in Brazil and in the United States.

Springtime in the Rockies has Miranda in the role of Rosita Murphy, a Brazilian of Irish origin who is hired as a secretary by the entrepreneur and singer Dan Christy (played by John Payne). In the film, he is the romantic interest of singer and dancer Vicky Lane (the rising star Betty Grable). 
Other supporting characters are Victor Prince, a creation of César Romero; he plays an adventurer who rivals Christy over Vicky Lane. Phoebe Gray, Lane's chambermaid, is Charlotte Greenwood, a comedian and dancer whose nickname at the time was Rubber Leg Lady. McTavish, Christy's page, is given an outstanding performance by celebrated comedian Edward Everett Horton. Harry James, big band leader, plays himself and was married to Grable for many years off the screen.

The story focuses on the shenanigans of the warfaring-thoughamorous pair of protagonists and takes place in the resort of Lake Louise, in the Canadian Rocky Mountains, which is seen in backprojections and carefully painted backdrops. The closing musical number, which gathers all the main characters, is a "Panamericana" allegory, blending rythms, melodies and choreographies of different latitudes in an effort to establish a political-cultural continuum from Canada to Argentina -as if there weren't hegemonies and subalternities. Nevertheless, differences are made evident by the presence of Carmen Miranda and the Bando da Lua (the musical group that accompanied her through her 17-year career in the United States). In a predominantly white/North American cast, they mark the narrative ethnically. Next to César Romero (who plays an Anglophone character, even though he dons a Mediterranean complexion and dances the tango very well), Miranda and her Bando play the non-white, foreign-accented characters. They would hardly be described as being white-perhaps not even Miranda, despite the fact that she was actually born in Portugal, having immigrated to Rio with her family when she was two years old. In other words, in an Eurocentric cast, these Latin American characters carry the burden of representing the ethnic Other.

On the other hand, the Canadian cultural context is absolutely rarefied in the narrative. The first images of Lake Louise are overwhelmed by close up shots of the glaring trumpet of Harry James, who plays for the enjoyment of an audience that fills an enormous ballroom. Here and there we can pinpoint the distant figure of a typical Canadian Mounty—redcoat, hat and all—amidst the tourists. Except those by the anodyne hotel clerks, there are no other explicit Canadian 
references in the narrative. The hotel of Lake Louise, as its surrounding landscape, seems to be limited to serve as the stage for the escapades and encounters of the Unitedstatesian protagonists.

However, when James and his Music Makers sum up their opening performance, the camera turns its focus onto a remote corner of the room, where two men talk. The shot is rather quick, but the ethnic and cultural identity of these characters is unmistakable. Dark skin, long and braided hair, waiters' uniform, lightly drunk overtones. There is no doubt: they are Native American (or Native Canadian, for that matter). These loners-for they are not seen in interaction with anybody else in the entire film-are the characters that carry their own burden: they represent the population of those Rocky Mountains. We hear a dialogue:

White Cloud

Hey, Running Deer, is this Harry James solid or is he solid?

Running Deer

Of course he is solid, White Cloud. But it's that mellow groove that sends me.

White Cloud

Check. (They walk on, pass by each other and leave the scene.)

In a way, in this dialogue these characters seem incapable of making more sense than simply the need to corroborate the action of the white protagonists (in this specific case, Harry James's music). Their presence does not add anything to the plot., and may even have been some joke of the director or the screenwriters - but that does not matter here. In this short interlude, the two Indians seem to be there to corroborate their own lack of sense. Their boogie-woogie lingo (an oblique reference to the absence of blacks?) and their niche in the narrative stress their alienation, which is deepened. when compared to the relative subalternity of other characters. Rosita, for instance, is just an eccentric secretary but, as much 
as Phoebe, Vicky's chambermaid, she shares spaces with her boss, to the point of escorting him to dinner; McTavish is not really a page or a butler, for the audience soon finds out he is a millionaire in disguise. ${ }^{11}$ The Indian waiters, on the other hand, appear to be as useful as the local color on the backdrops. But let's go back to Lake Louise.

Rosita, the unlikely secretary, reveals to her boss that she had been inadvertedly hired when he was drunk, on a stop over in Detroit. Still shaken from having a private secretary who fireshoots phrases in an unknown accent, wraps herself in colorful pieces of cloth and dons a turban from which two immense curtain pendants keep dangling, Christy is flabbergasted when she calls her six brothers. Rosita introduces them by reciting their names, some Portuguese, some Irish. Her brothers, for the Brazilian gaze, are the popular Bando da lua musicians.

The writers Walter Bullock, Ken Englund, Jacques Théry and Philip Wylie were certainly inspired by elements provided by the artists themselves. Many of Miranda's lines were especially written for her (and byher, such as all the Portuguese lines). Moreover, the excerpt just described features an event of biographical overtones. When she was called to work in the U.S. Miranda requested to be accompanied by the Bando da lua. She even wrote producer Lee Shubert a letter in which she stresses that point. ${ }^{12}$ As Shubert turned it down, Miranda summoned the support of Maxwel Jay Rice, executive of PanAmerican Airlines, and Alzira Vargas, daughter of the Brazilian president.

The Bando da lua saga may be seen in different ways-perhaps all of them true. First of all, Miranda was known for her generous hospitality to Brazilians in the United States. Second, the band would ensure the quality of her musical work, that might be hampered by samba-illiterate North American musicians. At the same time, her liaison with Bando member Aloysio de Oliveira must have supplied her with the necessary emotional security. Therefore, Miranda would not be alone in the U.S., as Rosita, in the diegetic Lake Louise, would not either.

The episode also shows the direct interest of the Vargas regime in the promotion of Miranda's international career as a Brazilian cultural ambassador. She was at once talented and popular; her persona blended 
elements of the street samba dancer and the sophisticated comedienne. Moreover, for a certain Brazilian elite, it was rather convenient to have a white representative, one whose presence seemed to obliterate AfricanBrazilian traits.

Therefore, it is possible to detect, in Miranda's oeuvre, a multicultural constellation that is not denied by her own origins. In her tragic biographical accounts we can perceive the sentiment of the fado (or fate), the most important musical genre of Portugal, full of sad narratives of submission to the inevitable and performed in a solemn way (this genre would be influential in the shaping of the chorinholiterally "little crying" or "weeping", the slow samba lament that could be heard in the serenades on the streets of Rio in the beginning of the $20^{\text {th }}$ century). On the other hand, Miranda's career is also noted for the sentiment of the samba (or "belly bumping", in the Quimbundo language of Angola $\left.^{13}\right)$, par excellence the extroverted expression of desire, of the carnival pageants of Rio. These two tendencies, fado and semba, filled the musical airs of Carmen Miranda's Rio de Janeiro, a city marked by an intense presence of Africa and Portugal.

After having been introduced to Christy in his hotel room, Carmen Miranda and the Bando perform a Brazilian version of the standard Chattanooga choo choo (by Mack Gordon and Harry Warren). The number raises specific questions on the ethnic representation in the film. As the self-reflexive lyrics in Portuguese expose, it is a version that alternates the rythms of samba and boogie-woogie. For Brazilian audiences, the words make up a message that fits the Good Neighbor Policy purposes. For the North American public, the act might show that the jazz had gone abroad. At the same time, it is worth remembering that in Springtime in the Rockies, as ocurred in most of the films produced in Hollywood at that time, the musical numbers are performed by white musicians. And the significant absence of African American characters or actors can be signaled when the Brazilians play Chattanooga choo choo, for their act indicates the connections of samba and jazz, which seem to emerge from an epistemological underground, to use the concept coined by Clyde Taylor. ${ }^{14}$ 
Hence Springtime in the Rockies asserts the black roots of those musical styles-as long as the North American audience sees the Brazilian characters as non-white. However, for Brazilian spectators the African absence might not be evident, as long as they would see Miranda and the Bando members as white (according to the Brazilian racial spectrum). Moreover, from what we can gather of the debates of her time, most of the issues discussed seemed to revolve around the representation of Brazilian nationality, not Brazilian admittedly problematic racial relations. And as we will see below, Miranda's role in Hollywood pointed to a transnational (and definitely multiethnic) positionality that somehow frustrated those who still hoped to see her as an ambassador of a certain Brazilian national (and whitened) culture.

The role of the secretary grows according to the farce played by the protagonist couple. Rosita is used, at first, as a jealousy bait for Dan Christy, who wants to provoke Vicky Lane. But Vicky and Rosita soon dismantle Christy's plans in a dialogue full of nonsense, in which the comic situations are provided by Miranda's lines and accent. Vicky is puzzled by the secretary's accent, but the spectators realize, little by little, Rosita's ingenuity and cleverness.

The two women meet in the powder room, as they fix their makeup before mirrors. The dialogue makes direct references to their ethnic differences.

Rosita

I like you people. You are being so nice to me.

Vicky

It's strictly unintended, I assure you.

Rosita

Thank you... I wish I was a blonde. On you it looks so good! Maybe I should bleach my hair.

Vicky

$\mathrm{O}$, you are frightfully witty, Miss Murphy! (angry) But my hair is naturally blond! 
Rosita

Well, shut my mouth! I won't breathe it to a soul! Nobody would know the difference!

Rosita thus displays both a keen wittiness and an ample ethnic and national mobility. To begin with, her name, Rosita, sounds Spanish, even though Brazilians are monoglotically Portuguese. ${ }^{15}$ Half Irish (Ulster? Eire?), half Brazilian (Luso-? Italian-? African-? Indian-?), Rosita admits the possibility of passing as someone identified with other ethnic identities - who knows? - if only by dying her hair blond. Her hair can serve as a mobile ethnic marker and Miranda's Rosita shows a mobile, flowing identity, turning her own miscegenation into a tool of adaptation, in a way that anticipates positionalities praised by many of today's cultural critics. Meanwhile, Vicky has her own ethnicity challenged by Rosita, who questions the authenticity of her blondness. (Which is quite ironic, since Betty Grable actually had her famous hair dyed.) Nevertheless, Rosita's ethnic mobility will be made more explicit later on in the film.

Rosita approaches McTavish, Christy's page. He seems to believe in her naiveté, but the dialogue is quickly dominated by Rosita's lines, which leave him dumbfounded. In many dialogues of Springtime in the Rockies Rosita is able to invert the intentions of the other characters, in a carnivalesque operation. Thus Christy does not want to hire her, but he does; Vicky does not trust her, but becomes her accomplice. The suspicious McTavish confides with Rosita and reveals his existencial saga, since he is a millionaire who takes up menial jobs in order to learn "what makes the heart tick". And she shoots:

Rosita

That's wonderful!

McTavish

What is it? (perplexed)

Rosita

It means we click! 
McTavish
O, does it?

Rosita

Yes!

So they click and their hearts tick, as the dialogue is absolutely led by Rosita's wit. McTavish would be the standard romantic interest reserved for Carmen Miranda in Hollywood: ugly, clumsy, non-sexual. ${ }^{16}$ Even their kisses are comical, noisy and behind doors-off the visual frame of both spectators and characters.

Later on, when she gets ready for her first dinner with her boss and a few millionaires, Rosita bumps into McTavish at his room door. She dons a spotlessly white ensemble of skirt, midriff and turban given by her boss. She says:

Rosita

You like the dress he got me?

McTavish

It's all right, yes.

Rosita

You are right. It needs some beads, some flowers, baubles, nuts, mix. I have an idea.

McTavish

Yes?

Rosita

Give me ten bucks.

McTavish

Ten bucks?

Rosita

(Quick) Yes, ten dollars, I need it, I'll pay you back. 
He draws the bills as Rosita's agile hands grab them in a flick of a second. She then walks away, saying that she has to go to the hotel shop -leaving a baffled McTavish once again.

When she returns to the scene, Rosita has a very different outfit. It is still the same white ensemble, now covered with fringes embroidered with colorful beads, lapis-lazuli accessories, silver buckles and topped with a blue turban. Hence Rosita's baiana outfit strinkingly conveys the cultural world of the two Native-Canadians-the same ones who had disappeared from the narrative. She thus temporarily lends the Brazilian emblem of (national, cultural, ethnic) identity in order to evoke a larger (transnational, transcultural, transethnic) identity. In this performance of Carmen Miranda, African-Brazilians and NativeAmericans find each other in similar, subaltern positionalities and their relationship produces a syncretism, an unforeseen dialogue between the Rocky Mountains and the distant African world of Bahia.

Dressed in that outfit, Rosita encounters Vicky in the ladies' room; dressed like that she makes ambiguous puns and people laugh their guts out at the dinner table. And that is how she steps into the ballroom in order to sing Tique-taque do meu coração (literally The ticking of my heart), making references to the world beyond the walls of the hotel of Lake Louise, to the world of the Indian waiters. And as if she were accentuating her positionality as a foreigner, she sings once again in Portuguese. It seems that the original copies shown in the U.S. did not feature subtitles for the lyrics - and without them it would be difficult for North American audiences to understand what makes Brazilian hearts tick. Moreover, her singing of the rather sad lyrics-Tique-taque do meu coração is a typical chorinho-is punctuated by smiles and slightly parodic gestures, resulting in an ironical reading that blends the sorrowful fado and the vivacious samba - details that non-Brazilian audiences would hardly grasp. But despite the exophony of the performance, the gracious gestures are there; the syncretic costume is there. Most certainly exotic for a white audience; perhaps familiar to a hypothetical Native-American audience. 
In Springtime in the Rockies, Carmen Miranda's Rosita seems to make clear that the Eurocentric world does not reserve an honorable place either for her or for the Natives of the Rocky Mountains. In this sense, her performance displays a political alignment that turns Tiquetaque no meu coração into a peformance of resistance.

I would like to thank my dear colleague David Lugowski for the illuminated reading of the English version of this essay, which I presented at the 2004 Society for Cinema and Media Studies Conference in Atlanta, and Erica Moura, my student at Universidade Federal de São Carlos, for her research work. My presence at that conference was sponsored by Fapesp — Fundação de Apoio à Pesquisa do Estado de São Paulo — and Universidade Paulista, São Paulo, Brazil.

\section{Notes}

1. "Carmen Miranda Da Da", Folha de S. Paulo, Octuber 22, 1991, and "Pride and shame", The New York Times, Oct. 10, 1991.

2. See Ana Rita Mendonça, Carmen Miranda foi a Washington. Rio: Record, 1999, p. 138.

3. Enciclopédia do Cinema Brasileiro, Fernão Ramos e Luiz Felipe Miranda (orgs.). São Paulo: Senac, 2000, p. 378.

4. Op. cit., p. 18 .

5. Ibid, pp. 24 and 41 .

6. Enciclopédia do Cinema Brasileiro, p. 378.

7. "Alô, alô, Carmen Miranda: do samba rasgado ao tique-taque do meu coração", Revista do Brasil, ca. 1985, p.100.

8. Ana Rita Mendonça, p. 19.

9. Op. cit.

10. Ibid. 
11. According to Horton's biography, he was wealthy enough not to depend on films to make a living.

12. Ana Rita Mendonça, p. 54.

13. Aurélio Buarque de Holanda Ferreira. Novo dicionário da língua portuguesa . Rio: Nova Fronteira, 1975, p. 1265.

14. Clyde Taylor, "Black Cinema in the Post-aesthetic Era", in Jim Pines and Paul Willemen (orgs.). Questions of Third Cinema . London: BFI Publishing, 1989.

15. The Portuguese version of her name would be Rosinha.

16. And even gay, as it is the case with the comic persona cultivated by Horton in his career. See William J. Mann, Nos bastidores de Hollywood. São Paulo: Landscape, 2002, pp. 165-170.

\section{References}

Ferreira, Aurélio Buarque de Holanda. "Samba." Novo dicionário da língua portuguesa. Rio: Nova Fronteira, 1975.

Mann, William J. Nos bastidores de Hollywood. São Paulo: Landscape, 2002. 165-170.

Mendonça, Ana Rita. Carmen Miranda foi a Washington. Rio: Record, 1999.

Taylor, Clyde. "Black Cinema in the Post-aesthetic Era." Questions of Third Cinema. Orgs. Jim Pines and Paul Willemen. London: BFI Publishing, 1989.

Veloso, Caetano. "Carmen Miranda Da Da," Folha de S. Paulo. 22 Oct.1991.

—. "Pride and shame." New York Times, 10 Oct. 1991.

Vieira, João Luiz. Enciclopédia do Cinema Brasileiro. Orgs. Fernão Ramos e Luiz Felipe Miranda. São Paulo: Senac, 2000. 